\title{
The Role of Nurses in the Implementation of Puskesmas Accreditation to Improve the Quality of Health Services in Morowali District
}

\author{
(Peran Perawat dalam Pelaksanaan Akreditasi Puskesmas untuk Peningkatan Mutu \\ Pelayanan Kesehatan di Kabupaten Morowali) \\ Muhamad Aswar; B. Resti Nurhayati; Suwandi; Endang Wahyati Y. \\ email: azwarfahrezy99@gmail.com \\ Master of Health Law, Soegijapranata Catholic University Semarang
}

\begin{abstract}
The role of nurses as health workers working at a Health Center (Puskesmas) is to provide health services through public and individual health efforts. The health services giving by the nurses are expected to increase the quality of health services in order to provide optimal services to communities conducted in integrated, comprehensive, and sustainable manners.

The objective of this study was to see the nurses' role in implementing Health Center accreditation in the efforts of improving the health services at Morowali District. This study used a socio-legal study approach having with analytical-descriptive specifications. It used primary and secondary data. The primary data gathering technique was through interviews with respondents and resource persons. The respondents consisted of nurses who worked in the Morowali District Health Centers while the resource persons were the heads of the Health Centers. The secondary data were obtained through related literature studies The role of nurses and the Health Centers accreditation at Morowali District were then qualitatively analyzed.

In the accrediation process as regulated by The Minister of Health's Regulation Nr. 46 of 2015 on Accreditation and The Minister of Health's Regulation Nr. 75 of 2014 on Health Centers there were three types of assessment instruments, namely management administration, public health care efforts, and individual health care efforts. The role of nurses in the accreditation covered the three instruments. The nurses here played an important role in improving the quality of health services as the goal of accreditation. The supporting factors of the nurses' role in the accreditation process dealt with legislations and human resources while the inhibiting factors dealt with the availability of health resources, the workload of the Health Center's workers, lack of facilities and infrastructure.
\end{abstract}

Keywords: role of nurses, health services quality, accreditation

Abstrak: Peran perawat sebagai salah satu tenaga kesehatan yang bekerja di puskesmas yang menyelenggarakan pelayanan kesehatan untuk peningkatan mutu pelayanan melalui upaya kesehatan masyarakat maupun upaya kesehatan perorangan. Pemberian pelayanan kesehatan yang dilakukan oleh perawat melalui upaya kesehatan tersebut diharapkan adanya peningkatan mutu pelayanan kesehatan guna memberikan pelayanan yang optimal kepada masyarakat yang dilaksanakan secara terpadu, menyeluruh, dan berkesinambungan. Tujuan penelitian adalah untuk mengetahui peran perawat dalam pelaksanaan akreditasi puskesmas untuk peningkatan mutu pelayanan kesehatan di Kabupaten Morowali.

Penelitian ini merupakan penelitian yuridis sosiologis dengan spesifikasi penelitian bersifat deksriptif analitik. Penelitian ini menggunakan data primer dan data sekunder. Metode pengumpulan data primer melalui wawancara dengan responden dan narasumber. Responden terdiri dari perawat yang bekerja di wilayah Kerja Puskesmas Kabupaten Morowali, sedangkan narasumber adalah Kepala Puskesmas. Data sekunder diperoleh melalui studi pustaka yang berhubungan Peran perawat dan akreditasi puskesmas di Kabupaten Morowali selanjutnya dianalisis secara kualitatif. 
SOEPRA Jurnal Hukum Kesehatan

TERAKREDITASI RISTEKDIKTI Peringkat 4

ISSN:2548-818X (media online) Vol. 7 (1) Juni 2021

Dalam pelaksanaan akreditasi yang diselenggarakan oleh puskesmas sebagaimana di atur dalam Permenkes No 46 Tahun 2015 tentang Akreditasi, Permenkes No 75 Tahun 2014 tentang Puskemas terdapat tiga jenis yang menjadi instrumen penilaian yaitu administrasi manajemen, upaya kesehatan masyarakat, dan upaya kesehatan peroorangan. Peran perawat dalam pelaksanaan akreditasi pada ketiga instrumen tersebut yakni administrasi manajemen, upaya kesehatan masyarakat dan upaya kesehatan perorangan. Perawat dalam pelaksanaan akreditasi berperan dalam peningkatan mutu pelayanan kesehatan sebagaimana tujuan dari akreditasi. Faktor pendukung terhadap peran perawat dalam pelaksanaan akeditasi yaitu faktor Perundang-undangan, dan sumber daya manusia. Sedangkan faktor penghambat yaitu ketersediaan sumber daya kesehatan, beban kerja petugas puskesmas, sarana dan prasarana.

Kata Kunci : Peran Perawat, mutu pelayanan kesehatan, Akreditasi

\section{PENDAHULUAN}

Kesehatan merupakan keadaan sejahtera dari badan, jiwa, yang memampukan tiap individu untuk hidup produktif secara sosial dan ekonomis. Dalam era reformasi saat ini, derajat kesehatan sangat berarti bagi pengembangan dan pembinaan sumber daya manusia sebagai salah satu modal dalam pelaksanaan pembangunan nasional yang pada hakikatnya merupakan pembangunan manusia seutuhnya.'Upaya untuk mengoptimalkan derajat kesehatan bagi setiap orang, yang menjadi bagian integral suatu kesejahteraan, diperlukan dukungan bagi penyelenggaraan berbagai kegiatan di bidang kesehatan.

Kesehatan sebagai kebutuhan dasar manusia merupakan hak bagi setiap warga negara, sebagaimana tercantum pada Pancasila dan Undang - Undang Dasar Negara Republik Indonesia Tahun 1945. Hal ini sesuai dengan cita-cita bangsa Indonesia. Berdasarkan Pasal 28 ayat (1) Undang-Undang Dasar Negara Republik Indonesia tahun 1945 bahwa "setiap orang berhak hidup sejahtera lahir dan batin, bertempat tinggal, dan mendapatkan lingkungan hidup yang baik dan sehat serta berhak memperoleh pelayanan kesehatan". Kesehatan sebagai salah satu unsur dari kesejahteraan umum harus dilaksanakan dan diwujudkan melalui berbagai upaya kesehatan dalam rangka pembangunan kesehatan secara terpadu dan menyeluruh didukung oleh suatu sistem kesehatan nasional. ${ }^{2}$

Tanggung jawab pemerintah mengenai fasilitas pelayanan kesehatan juga di atur dalam Pasal 17, Pasal 19 dan Pasal 21 Undang-Undang Nomor 36 tahun 2009 tentang Kesehatan, dimana disebutkan pada Pasal 17 bahwa “ Pemerintah bertanggung jawab atas ketersediaan akses terhadap informasi, edukasi, dan fasilitas pelayanan kesehatan untuk meningkatkan dan memelihara derajat kesehatan yang setinggi-tingginya". Pada Pasal 19 disebutkan bahwa "Pemerintah bertanggung jawab atas ketersediaan segala bentuk upaya kesehatan yang bermutu, aman, efisien, dan terjangkau", adapun pada Pasal 21 ayat (1) disebutkan bahwa "Pemerintah mengatur perencanaan, pengadaan, pendayagunaan, pembinaan, dan pengawasan mutu tenaga kesehatan dalam rangka penyelenggaraan pelayanan kesehatan".

Adapun tujuan dari pelayanan kesehatan itu sendiri yaitu untuk memenuhi kebutuhan individu atau masyarakat untuk mengatasi, menetralisasi atau menormalisasi semua masalah atau semua penyimpangan tentang kesehatan yang ada dalam masyarakat. Dengan meningkatnya tingkat pendidikan dan keadaan sosial ekonomi masyarakat, maka

\footnotetext{
1 Hendrik, 2018, Etika dan Hukum Kesehatan, Jakarta: EGC, Hal 26.

2 Cecep Tribowo, 2014, Etika Dan Hukum Kesehatan, Yogyakarta: Nuha Medika, Hal 1.
} 
SOEPRA Jurnal Hukum Kesehatan

TERAKREDITASI RISTEKDIKTI Peringkat 4

ISSN:2548-818X (media online) Vol. 7 (1) Juni 2021

kebutuhan dan tuntutan masyarakat akan kesehatan semakin meningkat sehingga tidak ada lagi upaya yang dapat dilakukan selain meningkatkan kinerja petugas kesehatan secara optimal dan menyelenggarakan pelayanan kesehatan dengan sebaik-baiknya. ${ }^{3}$

Puskesmas dalam memberi pelayanan kesehatan dan sebagai penyediaan sarana dan prasarana guna melindungi, menunjang dan meningkatkan kesehatan manusia menjadi salah satu bentuk perlindungan hukum dalam mendapatkan perhatian hukum. Puskesmas merupakan salah satu dalam prasarana pelayanan kesehatan yang menjadi andalan atau tolak ukur dari pembangunan kesehatan, sarana peran serta masyarakat, dan pusat pelayanan pertama yang menyeluruh dari suatu wilayah. ${ }^{4}$

Puskesmas dalam menjalankan fungsinya dapat mewujudkan diantara nya empat misi pembangunan kesehatan yaitu menyelenggarakan pembangunan kecamatan yang berwawasan pembangunan, mendorong kemandirian masyarakat dan keluarga untuk hidup sehat serta memelihara dan juga meningkatkan pelayanan kesehatan bermutu dan terjangkau serta memelihara dan meningkatkan kesehatan individu, kelompok dan masyarakat serta lingkungannya.

Melalui upaya-upaya yang telah disebutkan di atas maka diharapkan peningkatan mutu pelayanan kesehatan pada puskesmas tersebut berjalan dengan optimal. Peningkatan mutu kualitas dapat dinilai dari akreditasi puskesmas itu sendiri. Pada Pasal 8 Permenkes tentang Puskesmas disebutkan bahwa:

"Akreditasi Puskesmas adalah pengakuan terhadap Puskesmas yang diberikan oleh lembaga independen penyelenggara akreditasi yang ditetapkan oleh Menteri setelah dinilai bahwa Puskesmas telah memenuhi standar pelayanan Puskesmas yang telah ditetapkan oleh Menteri untuk meningkatkan mutu pelayanan Puskesmas secara berkesinambungan".

Permenkes Nomor 46 Tahun 2015 merupakan kebijakan yang menyusun standar dan instrumen penilaian akreditasi Puskesmas dalam menyediakan pelayanan tingkat pertama kepada masyarakat. Pada Pasal 3 dan 4 disebutkan bahwa Puskesmas wajib terakreditasi yang dapat dilakukan setiap 3 (tiga) tahun. Penetapan status akreditasi merupakan hasil akhir survey akreditasi oleh surveyor dan keputusan rapat lembaga independen penyelenggara akreditasi. Penetapan tersebut dibuktikan dengan adanya sertifikat akreditasi.

Pada Permenkes No. 46 tahun 2015 tentang Akreditasi Puskesmas, Klinik Pratama, tempat Praktik mandiri Dokter, dan tempat Praktik mandiri Dokter Gigi pada Pasal 9 disebutkan bahwa "penetapan Status Akreditasi Puskesmas terdiri dari (1) Tidak terakreditasi; (2) Terakreditasi dasar; (3) Terakreditasi madya, (4) Terakreditasi utama dan (5) Terakreditasi paripurna". Dinas Kesehatan Kabupaten / Kota mempersiapkan tahapan langkah Praakreditasi sampai pascaakreditasi Puskesmas dari pembentukan Tim Pendamping Kabupaten / Kota, Sarana dan Prasarana Puskesmas, Pengganggaran APBD Kabupaten/ Kota dan SDM sesuai Kompetensinya. Pendampingan praakreditasi merupakan rangkaian kegiatan penyiapan puskesmas agar memenuhi standar Akreditasi, sedangkan pendampingan pascaakreditasi merupakan kegiatan untuk memelihara serta meningkatkan

\footnotetext{
3 Konli Steven, 2014. Pelayanan Kesehatan Masyarakat Di Puskesmas Desa Gunawan Kecamatan Sesayap Kabupaten Tana Tidung

(http://ejournal.ip.fisipunmul.ac.id/site/wpcontent/uploads/2014/03/Jurnal\%20Steven\%20IP\%202010\%20(03-0114-12-07-23).pdf diakses tanggal 27 maret 2018 jam 22.27 WIB.

4 Dedi Alamsyah, 2012, Manajemen Pelayanan Kesehatan, Yogyakarta: Nuha Medika, hal 43.
} 
SOEPRA Jurnal Hukum Kesehatan

TERAKREDITASI RISTEKDIKTI Peringkat 4

ISSN:2548-818X (media online) Vol. 7 (1) Juni 2021

pencapaian standar Akreditasi secara berkesinambungan sampai dilakukan penilaian Akreditasi berikutnya. Akreditasi digunakan sebagai intrumen evaluasi ekternal terhadap mutu dan keselamatan Pasien. Untuk peningkatan mutu berkesinambungan setelah pascaakreditasi, tim Pendamping bekerja atas perintah dan tanggung jawab kepada kepala Dinas Kesehatan Kabupaten/Kota.

Data laporan Kementrian Kesehatan Republik Indonesia per akhir desember 2017 di Provinsi Sulawesi Tengah terdapat 193 puskesmas. Di mana dari 193 puskesmas di Sulawesi Tengah terdapat 79 puskesmas rawat inap dan 110 puskesmas non-rawat inap. Di kabupaten Morowali khususnya, terdapat 9 puskesmas pada masing-masing kecamatan yang ada di Kabuaten Morowali. Dari 9 puskesmas yang ada masing-masing puskesmas mempunyai karakteristik yang berbeda-beda. Terdapat 6 puskesmas dengan jenis tipe perawatan dan 3 jenis puskesmas jenis type non-perawatan. Artinya 3 puskesmas ini menyediakan fasilitas kesehatan rawat jalan dan 6 puskesmas merupakan puskesmas yang menyediakan fasilitas rawat inap bagi masyarakat. Dari 9 puskesmas tersebut terdapat 3 puskesmas yang terakreditasi madya yaitu puskesmas Lantula Jaya, puskesmas Wosu, dan puskesmas Bahonsuai.

Adapun keenam puskesmas yang lain statusnya 3 puskesmas sementara sedang dalam proses pelaksanaan akreditasi dan 3 puskesmas yang lain masih belum di programkan akreditasi hal ini dikarenakan penyelenggaraan akreditasi ini dilaksanakan secara bertahap. Menurut data dari dinas kesehatan tahun ini 3 puskesmas yang akan melakukan pelaksanaan akreditasi yaitu puskesmas Bungku Tengah, Puskesmas Ulunambo, dan Puskesmas Bahomotefe.

Di dalam penyelenggaraan akreditasi yang dilaksanakan oleh puskesmas tentu di dalamnya melibatkan semua sumber daya manusia yaitu tenaga kesehatan yang bekerja di puskesmas. Salah satu tenaga kesehatan yang bekerja di puskesmas yaitu tenaga perawat. Perawat memiliki peran dalam memberikan pelayanan kesehatan kepada masyarakat melalui setiap program yang ditugaskan oleh kepala puskesmas. Peran perawat dalam pelaksanaan akreditasi yaitu berada pada kegiatan upaya kesehatan masyarakat (UKM) dan upaya kesehatan peorangan (UKP). Perawat sebagai salah satu pemegang program dalam pelaksanaan pelayanan kesehatan wajib melaksanakan program tersebut demi terwujudnya pelayanan kesehatan yang optimal kepada masyarakat.

Akan tetapi pelayanan kesehatan yang diberikan kepada masyarakat tidak akan berjalan secara optimal apabila tidak ada kerja sama antara tenaga profesi yang lain seperti bidan, farmasi, dokter dan tenaga kesehatan yang lain. Dengan adanya kerja sama yang baik antar profesi dalam memberikan pelayanan kesehatan kepada masyarakat di harapkan adanya peningkatan kualitas pelayanan yang akan memberi manfaat kepada masyarakat sehingga masyarakat merasa puas dengan jasa yang diberikan oleh tenaga kesehatan di puskesmas. Dimana hal tersebut merupakan salah satu yang menjadi instrumen dalam penilaian akreditasi yaitu adanya upaya peningkatan kualitas dari pelayanan kesehatan tersebut.

\section{PERUMUSAN MASALAH}

Berdasarkan uraian dari latar belakang masalah tersebut di atas, dapat dirumuskan permasalahan sebagai berikut:

1. Bagaimana peran perawat dalam pelaksanaan akreditasi puskesmas untuk peningkatan mutu pelayanan kesehatan di Kabupaten Morowali? 
2. Faktor apa yang mendukung dan menghambat peran perawat dalam pelaksanaan akreditasi puskesmas untuk peningkatan mutu pelayanan kesehatan di Kabupaten Morowali ?

\section{METODOLOGI PENELITIAN}

1. Metode Pendekatan

Metode pendekatan yang digunakan pada penelitian ini adalah metode kualitatif dengan pendekatan yuridis sosiologis (socio-legal approach).

2. Spesifikasi Penelitian

Dalam penelitian ini, metode yang digunakan adalah metode penelitian deskriptif analitis. ${ }_{-}^{-}$

3. Subyek dan Obyek Penelitian

a. Subjek: Kepala Puskesmas dan Perawat.

b. Objek: Puskesmas.

4. Jenis Data

Jenis data yang digunakan pada penelitian ini adalah data primer dan data sekunder. Data primer adalah data yang diperoleh langsung dari sumbernya, salah satunya melalui wawancara mendalam. Sedangkan data sekunder adalah data yang diperoleh peneliti dari penelitian kepustakaan dan pengelolaan orang lain yang sudah tersedia dalam bentuk sebuah buku atau bentuk dokumentasi yang biasanya disediakan diperpustakaan umum atau perpustakaan pribadi. ${ }^{6}$

5. Metode Pengumpulan Data

Untuk memperoleh data dari penelitian ini maka peneliti menggunakan metode pengumpulan data primer dan data sekunder. Data primer merupakan data yang diperoleh langsung dari objek yang diteliti, sedangkan data sekunder yakni data yang sudah dalam bentuk jadi seperti data dokumen dan publikasi. ${ }^{7}$

a. Studi Kepustakaan

Data kepustakaan dapat diperoleh melalui kepustakaan yang bersumber dari perturan perundang-undangan, buku-buku, dokumen resmi, publikasi dan hasil penelitian. ${ }^{8}$ Tujuan dan kegunaan studi pustaka pada dasarnya adalah menunjukan jalan pemecahan masalah penelitian.

b. Studi Lapangan

Studi lapangan bertujuan untuk mengumpulkan data primer. Data primer dalam penelitian ini diperoleh dengan cara wawancara.

\section{PEMBAHASAN}

\section{A. Gambaran Umum Lokasi Penelitan}

Letak geografis, Kabupaten Morowali yaitu $01^{\circ} 3112$ - $03^{\circ} 4648$ LS dan antara $121^{\circ} 0224$ $123^{\circ} 1536$ BT. Kabupaten Morowali merupakan sebuah kabupaten yang berada

\footnotetext{
5 Nyoman Dantes, 2012, Metode Penelitian, Yogyakarta: CV Andi Offset, Hal. 51.

${ }^{6}$ Ali Zainuddin, 2016, Metode Penelitian Hukum, Jakarta: Sinar Grafika, Hal. 106.

7 Rianto Adi, 2005, Metode Penelitian Sosial dan Hukum, Jakarta: Granit, Hal 57.

${ }^{8}$ Ali Zainuddin, Op.,cit, Hal 170.
} 
di provinsi Sulawesi Tengah Indonesia. Kabupaten ini mempunyai luas sebesar 15.490,12 km2. Pada tahun 2016 jumlah penduduk terhitung 113.132 jiwa. Morowali merupakan kabupaten terluas ke-10, dengan tingkat kepadatan ke-9, serta memiliki populasi terbanyak dengan urutan ke-12 di Sulawesi Tengah. Terdapat 9 kecamatan dan 245 desa/kelurahan yang bernaung padaKabupaten Morowali. Adapun batas-batas wilayah Kabupaten Semarang adalah sebagai berikut:

a. Sebelah utara berbatasan dengan wilayah Kabupaten Tojo Una-Una

b. Sebelah timur berbatasan dengan Kabupaten Poso, Tojo Una-Una, Sulawesi Selatan dan Sulawesi Tengah.

c. Sebelah selatan berbatasan dengan wilayah Propinsi Sulawesi Selatan dan Sulawesi Tenggara

d. Sebelah barat berbatasan dengan Perairan Teluk Tolo dan Kabupaten Banggai

Penelitian ini meneliti tentang "peran perawat dalam pelaksanaan akreditasi puskesmas untuk peningkatan mutu pelayanan kesehatan di Kabupaten Morowali". Penelitian ini dilaksanakan pada pada tiga puskesmas dengan jenis akreditasi yang berbeda. Adapun tiga puskesmas tersebut yaitu Puskesmas Laantula Jaya, Puskesmas Ulunambo, dan Puskesmas Bahodopi.

Subyek penelitian melalui wawancara yaitu Kepala Dinas Kesehatan Kabupaten Morowali, Kepala Puskesmas Laantula jaya, Perawat Pemegang Program Puskesmas Lantula Jaya, Kepala Puskesmas Ulunambo, Perawat Pemegang Program Puskesmas Ulunambo, dan Kepala Puskesmas Bahodopi, serta Perawat Pemegang Program Puskesmas Bahodopi.

B. Peran Perawat dalam Pelaksanaan Akreditasi Puskesmas untuk Peningkatan Mutu Pelayanan Kesehatan

Berdasarkan Rencana Strategis Kementerian Kesehatan Tahun 2015-2019, program pembangunan kesehatan 2015-2019 adalah Indonesia Sehat dengan sasaran yang mengacu pada RPJMN 2015-2019, salah satunya yaitu meningkatnya akses dan mutu pelayanan kesehatan dasar dan rujukan terutama di daerah terpencil, tertinggal dan perbatasan yang sesuai dengan UU Kesehatan bahwa "setiap orang mempunyai hak dalam memperoleh pelayanan kesehatan yang aman, bermutu, dan terjangkau".

Peraturan Menteri Kesehatan No 75 tahun 2014 tentang Puskesmas, Puskesmas merupakan fasilitas pelayanan kesehatan yang menjadi garda depan dalam penyelenggaraan upaya kesehatan dasar khususnya dalam era JKN saat ini. Adapun kebijakan yang dilakukan oleh Kementerian Kesehatan dalam upaya peningkatan mutu pelayanan di fasilitas kesehatan tingkat pertama khususnya Puskesmas adalah dengan menerbitkan Peraturan Menteri Kesehatan No 46 tahun 2015 tentang Tentang Akreditasi Puskesmas, Klinik Pratama, Tempat Praktik Mandiri Dokter, Dan Tempat Praktik Mandiri Dokter Gigi.

Berdasarkan hasil penelitian yang dilakukan dengan wawancara Kepala Dinas Kesehatan Kabupaten Morowali di dapatkan hasil bahwa dalam upaya peningkatan mutu pelayanan kesehatan di fasilitas kesehatan tingkat pertama adalah dengan melaksanakan akreditasi sesuai dengan Peraturan Menteri Kesehatan No 46 tahun 2015 tentang Akreditasi Puskesmas, Klinik Pratama, Tempat Praktik Mandiri Dokter, dan Tempat Praktik Mandiri Dokter Gigi. Hal tersebut bertujuan untuk menjamin bahwa perbaikan mutu, 
peningkatan kinerja dan penerapan manajemen risiko dilaksanakan secara berkesinambungan di Puskesmas. ${ }^{9}$

Selanjutnya Kepala Dinas Kesehatan mengatakan bahwa dari 9 puskesmas yang berada di wilayah Kabupaten Morowali yang telah terakreditasi tiga puskesmas yaitu Puskesmas Laantula Jaya, Puskesmas Bahonsuai, dan Puskesmas Wosu dengan jenis akreditasi Madya. Selain dari tiga puskesmas yang telah terakreditasi pada tahun 2018, tiga puskesmas sedang dalam proses untuk pelaksanaan akreditasi yaitu Puskesmas Ulunambo, Puskesmas Bahomotefe, dan Puskesmas Bungku Tengah. Sedangkan untuk puskesmas yang belum terakreditasi yaitu Puskesmas Kaleroang, Puskesmas Lafeu, dan Puskesmas Bahodopi. Jadi untuk pelaksanaan akreditasi ini memang dilaksanakan secara bertahap..$^{10}$

Upaya yang dilakukan oleh Dinas Kesehatan dalam pelaksanaan akreditasi puskesmas yaitu memberikan pendampingan pada puskesmas yang akan melaksanakan akreditasi dengan membentuk tim pendamping. Tim pendamping ini terdiri dari dua yaitu tim pendamping praakreditasi dan tim pendamping pasca akreditasi. Peraturan Menteri Kesehatan No 46 tahun 2015 tentang Tentang Akreditasi Puskesmas, pada Pasal 11 ayat (1) disebutkan bahwa "Pendampingan praakreditasi merupakan rangkaian kegiatan penyiapan Puskesmas, Klinik Pratama, tempat praktik mandiri dokter, dan tempat praktik mandiri dokter gigi agar memenuhi standar Akreditasi". Selanjutnya pada Pasal 12 ayat (1) disebutkan bahwa "Pendampingan pascaakreditasi merupakan kegiatan untuk memelihara serta meningkatkan pencapaian standar Akreditasi secara berkesinambungan sampai dilakukan penilaian Akreditasi berikutnya".

Peran tenaga kesehatan dalam pelaksanaan akreditasi sangat penting karena sebagai pemberi pelayanan kesehatan yang diselenggarakan oleh puskesmas. Perawat masuk dalam bagian tenaga kesehatan, bekerja di puskesmas memiliki peranan dalam pelaksanaan akreditasi puskesmas sesuai dengan tugas dan tanggung jawabnya. Dalam pelaksanaan akreditasi puskesmas terdapat tiga kelompok yang menjadi instrumen penilaian yaitu kelompok Administrasi Manajemen, kelompok Upaya Kesehatan Masyarakat (UKM), dan kelompok Upaya Kesehatan Perorangan (UKP). Jadi dari ketiga instrumen yang menjadi penilaian dalam pelaksanaan akreditasi puskesmas maka dibentuk kelompok kerja yang beranggotakan tenaga kesehatan yang selanjutnya akan bekerja sesuai dengan tugas tanggung jawabnya berdasarkan kelompok kerja tersebut.

Dalam pelaksanaan akreditasi puskesmas terdapat tiga kelompok pelayanan yang menjadi instrumen penilaian akreditasi yaitu:

1) Kelompok administrasi manajemen,

2) Kelompok Upaya Kesehatan Masyarakat (UKM),

3) dan Kelompok Upaya Kesehatan Perorangan (UKP).

Pada kelompok administrasi manajemen kegiatan yang dilakukan terdiri dari tiga bab yaitu:

1) Bab I tentang Penyelenggaraan Pelayanan Puskesmas (PPP),

2) Bab II tentang Kepemimpinan dan Manajement Puskesmas,

3) Bab III tentang Peningkatan Mutu Puskesmas.

9 Hasil wawancara dengan Kepala Dinas Kesehatan Kabupaten Morowali, pada tanggal 30 Agustus 2018

${ }^{10}$ Hasil wawancara dengan Kepala Dinas Kesehatan Kabupaten Morowali, pada tanggal 30 Agustus 2018 
Adapun kegiatan yang dilaksanakan penyelenggaraan pelayanan puskesmas yaitu melakukan penilaian kebtuhan masyarakat dengan melakukan pertemuan terhadap tokoh-tokoh masyarakat, sektor terkait, dan kegiatan survey sebagai bahan penyusunan rencana puskesmas. Hasil dari pertemuan tersebut kepala puskesmas membuat rencana usulan kegiatan (RUK) dan rencana pelaksana kegiatan (RPK). Kegiatan yang dilaksanakan tentang kepemimpinan dan manajemen pukesmas yaitu Membuat analisis pertimbangan tata ruang daerah dan rasio ketersediaan pelayanan kesehatan dan jumlah penduduk dituangkan dalam rencana strategis atau rencana pembangunan Puskesmas.

Pada kegiatan yang dilakukan untuk peningkatan mutu puskesmas yaitu menyusun pedoman (manual) mutu dan kinerja bersama dengan Pimpinan Puskesmas yang akan menjadi acuan bagi Pimpinan, Penanggung jawab dari Upaya (Pusat Kesehatan Masyarakat) Puskesmas dan Pelaksana Kegiatan Puskesmas.

Selanjutnya pada kelompok usaha kesehatan masyarakat terdiri dari tiga bab juga yaitu:

1) Bab IV tentang Upaya Kesehatan Masyarakat yang Berorientasi Sasaran (UKMBS),

2) Bab $V$ tentang Kepemimpinan, Manajemen Upaya Kesehatan Masyarakat (KMUKM),

3) Bab VI tentang Sasaran Kinerja Upaya Kesehatan Masyarakat.

Upaya kesehatan masyarakat yang berorientasi sasaran yaitu melakukan identifikasi kebutuhan dan harapan masyarakat, kelompok masyarakat, dan individu yang merupakan sasaran kegiatan. Pada kegiatan kepemimpinan, manajemen upaya kesehatan masyarakat yaitu meningkatkan kompetensi, harapannya agar mampu untuk mengelola sesuai dengan tujuan yang harus dicapai. Upaya peningkatan kompetensi dilakukan melalui pelatihan-pelatihan maupun pendidikan yang dipersyaratkan sebagai penanggung jawab. Adapun kegiatan yang dilakukan oleh sasaran kinerja upaya kesehatan masyarakat yaitu Penanggung jawab UKM Puskesmas bersama pelaksana melakukan pertemuan membahas kinerja dan upaya perbaikan yang perlu dilakukan.

Pada kelompok upaya kesehatan perorangan terdiri dari tiga bab yaitu:

1) Bab VII Layanan Klinis yang Berorientasi Lapangan (LKBP),

2) Bab VIII Manajemen Penunjang Layanan Klinis (MPLK), dan

3) Bab IX Peningkatan Mutu Klinis dan Keselamatan Pasien (PMKP).

Dalam LKBP salah satu kegiatan yang dilakukan yaitu memenuhi kebutuhan pasien dalam proses pendaftaran dan di dukung oleh sarana dan lingkungan yang memadai. Selanjutnya salah satu kegiatan dalam MPLK yaitu pelayanan laboratorium, pelayanan obat, manajemen informasi-rekam medis, manajement lingkungan, manajemen peralatan, dan manajemen sumber daya manusia. Adapun PMKP kegiatannya yaitu perencanaan, monitoring, dan evaluasi mutu layanan klinis dan keselamatan.

Peran perawat dalam pelaksanaan akreditasi Puskesmas Laantula Jaya, Puskesmas Ulunambo, dan Puskesmas Bahodopi yaitu sebagaimana di uraikan dibawah ini:

1. Puskesmas Laantula Jaya

Perawat memiliki peran sebagai tenaga kesehatan, bekerja di Puskesmas gunaterselenggaranya pelayanan kesehatan. Peran ialah pelaksanaan dari hak juga kewajiban seorang sesuai dengan status sosial yang dimilikinya. peranan dapat 
diidentikkan sebagai kewajiban atau hak. Kewajiban merupakan peranan (role) imperatif karena tidak boleh tidak dilaksanakan, sedangkan hak adalah peranan (role) yang fakultatif sifatnya karena boleh tidak dilaksanakan. Peran perawat dalam upaya kesehatan masyarakat maupun upaya kesehatan perorangan, merupakan peran imperatif (kewajiban) sehingga berdasarkan peran tersebut perawat wajib menyelenggarakan upaya kesehatan tersebut dalam rangka meningkatkan derajat kesehatan setiap masyarakat yang setinggi-tingginya. Adapun peran fakultatif (hak) yang sifatnya boleh tidak dilaksanakan yaitu perawat dalam mengikuti pendidikan berkelanjutan ke tahap yang lebih tinggi. Akan tetapi apabila perawat memiliki keinginan untuk melanjutkan pendidikan maka pemiliki atau pengelola fasilitas pelayanan kesehatan berhak memfasilitasi perawat tersebut.

Dalam menjalankan tugas dan profesinya, tenaga kesehatan berhak mendapat imbalan dan perlindungan hukum atas dasar prestasi kerja, pengabdian, kesetiaan, berjasa pada negara atau meninggal dunia dalam melaksanakan tugas. Tenaga kesehatan memiliki kewenangan dalam menyelenggarakan pelayanan kesehatan sesuai dengan bidang keahlian yang dimiliki. ${ }^{11}$

Perawatan kesehatan masyarakat merupakan sintesa dari praktek keperawatan dan praktek kesehatan masyarakat yang di aplikasikan untuk meningkatkan kesehatan dan pemeliharaan kesehatan dari masyarakat. Perawatan kesehatan masyarakat bertujuan membantu masyarakat dalam upaya meningkatkan derajat kesehatan masyarakat. ${ }^{12} \mathrm{Hal}$ tersebut sejalan dengan hasil wawancara yang dilakukan terhadap perawat bahwa dalam upaya penyelenggaran pelayanan kesehatan yang berorientasi kepada masyarakat dilaksanakan melalui penyuluhan program pengendalian dan pemberantasan penyakit menular ( $\mathrm{P} 2 \mathrm{M}$ ) dalam kelompok UKM didapatkan hasil yaitu kegiatan dalam program $\mathrm{P}_{2} \mathrm{M}$ ini meliputi:

a) Upaya pencegahan penyakit dan

b) Upaya pemberantasan penyakit. ${ }^{13}$

Kegiatan pemberantasan penyakit menular dan penyakit tidak menular dilaksanakan didalam dan luar gedung. Kegiatan didalam gedung meliputi melakukan pemeriksaan dan tatalaksana penderita pneumonia, diare, TB, kusta melakukan pemeriksaan dan tatalaksana penderita penyakit tidak menular, melakukan rujukan kasus diare, TB, kusta yang tidak bisa ditangani puskesmas, pengambilan obat dan pengawasan minum obat, melakukuan konseling, dan membuat pencatatan dan pelaporan kegiatan. Adapun kegiatan yang dilaksanakan diluar gedung meliputi melakukan pencarian kasus penderita secara aktif seperti pelacakan kasus dan kunjungan rumah. Melakukan pelacakan kasus mangkir (TB), melakukan penyuluhan kepada masyarakat, melakukan kordinasi dengan lintas sektor dan melakukan fogging dan abetisasi. Perawat mengatakan bahwa setelah puskesmas melakukan akreditasi seluruh kegiatan yang dilaksanakan lebih terorganisir.

Hasil wawancara yang didapatkan dari narasumber perawat dalam upaya kesehatan perorangan yaitu kegiatan yang dilakukan lebih berfokus pada pelaksanaan pelayanan

\footnotetext{
${ }^{11}$ Cecep Tribowo, Yulia Fauziah, Op.Cit, Hal 21.

${ }^{12}$ Ratnawati Emmelia, 2014, Op.Cit, Hal 97-98.

13 Hasil Wawancara dengan perawat pemegang program pengendalian dan pemberantasan penyakit menular, pada tanggal 2 September 2018.
} 
kesehatan di puskesmas. Perawat mengatakan bahwa dalam puskesmas sudah terdapat sub-sub dalam penyedia layanan kesehatan. Jadi apabila ada pasien yang datang memeriksakan kesehatan ke puskesmas harus berdasarkan alur pelayanan yang harus diikuti. Terkecuali beberapa kasus yang bersifat darurat (emergency), kemungkinan tidak mengikuti alur yang baku bisa langsung menuju ruang rawat darurat atau ruang tindakan yang terdapat di puskesmas.

Salah contohnya yaitu dalam ruangan unit gawat darurat terdapat beberapa standar operasional prosedur atau prosedur tetap dalam pelaksanaan tindakan kepada pasien seperti protap dalam observasi kasus gawat. Prosedur tetap (protap) dalam penanganan pasien gawat yaitu:

1. Melakukan observasi terhadap penderita gawat

2. Melakukan observasi sesuai dengan tingkat kegawatannya,dilakukan tiap 5-15 menit.

3. Observasi oleh perawat, dan jika perlu oleh dokter.

4. Observasi diperlukan untuk hal-hal di bawah ini :

a) Keadaan umum penderita

b) Kesadaran penderita

c) Kelancaran jalan nafas (Air Way).

d) Kelancaran pemberian oksigen (O2)

e) Tanda-tanda vital seperti : Tensi, Nadi, Respirasi / pernafasan, Suhu

f) Kelancaran tetesan infus

5. Jikadari observasi didapatkankondisipasien semakin menurun paramedis perawat harus melakukan pelaporan kepada Dokter penaggung jawab saat itu/yang bertugas (diluar jam kerja yaitu via telepon).

6. Jika kasus yang sedang ditangani penyakitnya diluar kompetensi Dokter UGD maka dilakukanrujukan.

7. Dilakukan observasi dengan batas maksimal 2 jam, dan selanjutnya keputusan dari penderita ingin pulang atau rawat inap.

8. Dilakukan pencatatan pada kartu status penderita(les UGD) / lembar observasi untuksetiap perkembangan penderita selama observasi berlangsung.

9. Tahap selanjutnya jika observasi selesai dilakukan penetuan apakah penderita perlu rawat jalan / rawat inap / rujuk.

Mutu pelayanan kesehatan akan dirasakan berkualitas oleh para penggunanya apabila hal-hal yang sampaikan kepada para penggunanya melampaui harapan. Adapun penilaian pengguna jasa kesehatan akan ditujukan kepada substansi pesan yang disampaikan, bagaimana cara penyampaiannya dan kualitas jasa yang diterima para pemakainya. Kualitas jasa pelayanan kesehatan sangat ditentukan oleh kebutuhan atau ekspektasi pengguna yang sudah terpenuhi dan diterima tepat waktu. Untuk itu, para penyedia jasa pelayanan kesehatan harus mampu memenuhi harapan pengguna jasa. ${ }^{14}$

2. Puskesmas Ulunambo

Berdasarkan wawancara yang dilakukan terhadap narasumber kepala puskesmas didapatkan hasil yaitu untuk mendukung pelaksanaan akreditasi puskesmas yang terdapat pada tiga pokok pelayanan yang menjadi instrumen penilaian yaitu

${ }^{14}$ Muninjaya Gde, Op.Cit, Hal 15. 
kelompok Administrasi Manajemen, kelompok Upaya Kesehatan Masyarakat, dan kelompok Upaya Kesehatan Perorangan. Jadi dari tiga kelompok tersebut dibentuk kelompok kerja (pokja) dimana pada setiap pokja memiliki ketua yang akan mengkordinir anggotanya terkait dengan kegiatan-kegiatan yang dilaksanakan setiap pokja. Jadi ketiga hal tersebut yang dipersiapkan dalam memenuhi instrument penilaian akreditasi yang ada dengan berbagai elemen-elemen penilaian untuk pelaksanaan akreditasi. ${ }^{15}$

Sebagaimana tujuan dari akreditasi yaitu untuk meningkatkan standar mutu pelayanan kesehatan di Puskesmas dan keselamatan pasien, Kepala Puskesmas mengatakan salah satu hal yang dilakukan untuk meningkatkan mutu pelayanan yang menjadi instrumen penilaian dalam akreditasi puskesmas yaitu dengan meningkatkan kualitas sumber daya manusia yang tersedia. Sumber daya manusia kesehatan merupakan tatanan yang menghimpun berbagai upaya perencanaan, pendidikan, pelatihan serta pendayagunaan tenaga kesehatan secara terpadu dan saling mendukung guna mencapai derajat kesehatan masyarakat setinggi-tingginya dan mampu menggembangkan atau meningkatkan kinerja profesionalnya yang ditunjukkan dengan ketajaman analisis permasalahan kesehatan, merumuskan dan melakukan advokasi program dan kebijakan kesehatan dalam rangka pengembangan dan pengelolaan sumber daya manusia kesehatan. ${ }^{16}$

Pada upaya kesehatan masyarakat salah satu kegiatan yang dilaksanakan dengan berorientasi sasaran ini yaitu kegiatan promosi kesehatan. Kegiatan tersebut termasuk dalam upaya pelayanan kesehatan promotif yaitu suatu kegiatan dan/atau serangkaian kegiatan pelayanan kesehatan yang lebih mengutamakan kegiatan yang bersifat promosi kesehatan. Tujuan dari pelaksanaan promosi kesehatan tersebut yaitu untuk meningkatkan dan memelihara kesehatan, mencegah penyakit, serta memulihkan kesehatan yang ditujukan kepada kelompok maupun masyarakat. ${ }^{17}$

Berdasarkan hal tersebut narasumber perawat mengatakan penyuluhan dan konseling merupakan salah satu tugas pokok dalam upaya kesehatan masyarakat berdasarkan dengan temuan kasus di lapangan. Adapun kegiatan promosi kesehatan yang dilakukan yaitu penyuluhan tentang PHBS. Untuk kegiatan PHBS yang menjadi sasaran kegiatan yaitu warga, kader, sekolah dan tempat-tempat umum. Dari hasil identifikasi petugas kesehatan terhadap perilaku hidup bersih dan sehat ini khususnya daerah pulau masih sangat kurang. Hal tersebut yang menjadi fokus Puskesmas dalam melaksanakan penyuluhan terkait pentingnya perilaku hidup bersih dan sehat. Narasumber perawat mengatakan khususnya daerah pulau harus ada upaya pemicuan untuk jamban sehat, karena sebagian besar masyarakat daerah pulau sudah terbiasa untuk buang air besar ke pantai. Jadi agar perilaku hidup bersih dan sehat bisa terlaksana dengan baik, maka lintas program seperti bidan desa, kesling, sanitarian dan lintas sektor harus turut aktif dalam memonitoring kegiatan tersebut. ${ }^{18}$

Perawat mengatakan bahwa dengan dilaksanakannya kegiatan ini diharapkan masyarakat setempat memiliki kesadaran, kemauan, dan kemampuan untuk

\footnotetext{
${ }^{15}$ Hasil Wawancara dengan Kepala Puskesmas Ulunambo, pada tanggal 10 September 2018.

16 Ibid.,

17 Sri Handayani, Op., Cit Hal 64.

18 Hasil Wawancara dengan penanggung jawab program upaya kesehatan masyarakat, pada tanggal 10 September 2018.
} 
mendorong kemandirian masyarakat dan pola hidup keluarga agar berperilaku sehat. Dengan demikian akan tercipta lingkungan yang sehat dan terwujudnya derajat kesehatan yang optimal. Peraturan Menteri Kesehatan No 39 tahun 2016 tentang pedoman penyelenggaraan program Indonesia Sehat dengan pendekatan keluarga pada Pasal 3 ayat (1) butir I disebutkan bahwa "Dalam rangka penyelenggaraan Program Indonesia Sehat Dengan Pendekatan Keluarga, ditetapkan 12 (dua belas) indikator utama sebagai penanda status kesehatan sebuah keluarga salah satunya yaitu keluarga mempunyai akses atau menggunakan jamban sehat. Jadi upaya pemicuan jamban sehat merupakan salah satu indikator dalam penyelenggaraan Indonesia Sehat dengan pendekatan keluarga.

Selanjutnya hasil wawancara terhadap narasumber perawat dalam kelompok kerja (pokja) upaya kesehatan perorangan dikatakan bahwa dalamLayanan Klinis yang Berorientasi Pasien (LKBP) salah satu kegiatan yang dilakukan yaitu memenuhi kebutuhan pasien dalam proses pendaftaran dan didukung oleh sarana dan lingkungan yang memadai. Pemenuhan kebutuhan pasien akan pelayanan kesehatan sangat penting sesuai dengan Undang-Undang No 39 tahun 2009 tentang kesehatan pada Pasal 5 ayat (2) disebutkan bahwa "Setiap orang mempunyai hak dalam memperoleh pelayanan kesehatan yang aman, bermutu, dan terjangkau". Selanjutnya pada Pasal 7 disebutkan bahwa "Setiap orang berhak untuk mendapatkan informasi dan edukasi tentang kesehatan yang seimbang dan bertanggung jawab". ${ }^{19}$

Pada upaya kesehatan perorangan ini perawat mengatakan bahwa dalam upaya meningkatkan mutu pelayanan di puskesmas perawat dalam memberikan pelayanan berdasarkan standar profesi dan standar prosedur operasional dengan mengutamakan keamanan dan keselamatan pasien. Dalam pelayanan perorangan perawat lebih berfokus pada pemberian pelayanan di ruangan keperawatan. Sebelum pasien memeriksakan kesehatan maka ada alur pelayanan yang harus diikuti oleh pengunjung/pasien. Dalam penerimaan pasien yang berobat ke puskesmas terdapat standar operasional prosedur yang harus dilaksanakan. Adapun SOP dalam penerimaan pasien yaitu:

1. Menerima pasien dan keluarganya dengan ramah.

2. Sebelum penderita dibaringkantimbang berat badan, hal ini dilakukan bila pasien dapat berdiri.

3. Melakukan pengkajian data dengan anamnese dan pemeriksaan fisik.

4. Melakukan pelaporan pasien kepada penanggung jawab ruangan.

5. Memberi penjelasan kepada pasien dan keluarganya terkait tata tertib yang berlaku di puskesmas.

6. Melakukan pencatatan data hasil pengkajian pada catatan medik dan catatan perawatan pasien.

7. Memberitahu prosedur perawatan atau tindakan yang akan dilakukan.

Hasil wawancara terhadap perawat yaitu dalam menerima pasien yang berobat ke puskesmas harus sesuai dengan SOP yang berlaku di puskesmas. Dalam upaya meningkatkan mutu pelayanan perawat mengatakan bahwa semua tindakan yang

19 Hasil Wawancara dengan perawat penanggung jawab program upaya kesehatan perorangan, pada tanggal 10 September 2018. 
dilakukan harus berdasarkan standar profesi dan juga standar prosedur operasional. Untuk melindungi kepentingan pemakai jasa pelayanan kesehatan, ditetapkan bahwa upaya yang dilakukan untuk menimbulkan kepuasan tersebut harus sesuai dengan kode etik serta standar pelayanan kesehatan profesi. Suatu pelayanan kesehatan, meskipun dapat memuaskan klien, tetapi apabila diselenggarakan tidak sesuai dengan kode etik serta standar pelayanan profesi, dan bukanlah pelayanan kesehatan yang bermutu. ${ }^{20}$

Berdasarkan hasil wawancara dengan narasumber dapat ditarik simpulan bahwa sebagaimana tujuan dari pelaksanaan akreditasi yaitu untuk pembinaan peningkatan mutu kinerja melalui perbaikan yang berkesinambungan terhadap sistem manajemen, sistem manajemen mutu, sistem penyelenggaraan pelayanan klinis, serta penerapan manajemen resiko, puskesmas Ulunambo berupaya menyelenggarakan pelayanan sesuai standar akreditasi. Namun dalam pelaksanaan di lapangan masih terdapat beberapa kekurangan dari program yang dilaksanakan oleh puskesmas. Pada upaya kesehatan masyarakat terkait program promosi kesehatan masih harus ditingkatkan penyuluhan-penyuluhan kepada masyarakat berkaitan dengan permasalahan yang teridentifikasi salah satunya yaitu pentingnya perilaku hidup bersih dan sehat. Adapun untuk program upaya kesehatan perorangan lebih berfokus pada pemberian pelayanan dalam puskesmas seperti pelayanan pada ruang rawat inap, ruang instalasi gawat darurat, dan penerimaan pasien yang berobat.

3. Puskesmas Bahodopi

Puskesmas dalam fasilitas pelayanan kesehatan termasuk dalam pelayanan kesehatan tingkat pertama yang menjadi garda terdepan dalam upaya pembangunan kesehatan nasional. Pelayanan kesehatan tingkat pertama yaitu pelayanan kesehatan dasar yang diberikan oleh dokter dan dokter gigi di puskesmas, puskesmas perawatan, tempat praktik perorangan, klinik pratama, klinik umum di balai/lembaga pelayanan kesehatan, dan rumah sakit pratama. Peran tenaga kesehatan dalam hal ini perawat dalam penyelenggaraan peningkatan mutu pelayanan kesehatan melalui kegiatan akreditasi sangat penting. Hal tersebut demi terwujudnya derajat kesehatan masyarakat yang setinggi-tingginya.

Dalam penyelenggaraan upaya kesehatan yang dilaksanakan oleh puskesmas terdapat beberapa upaya kesehatan pokok dan upaya pengembangan. Selain upaya kesehatan pokok dan pengembangan puskesmas dalam menjalankan tugas dalam rangka mendukung terwujudnya kecamatan sehat puskesmas menyelenggarakan fungsi upaya kesehatan masyarakat dan upaya kesehatan perorangan.

Pada Pasal 30 ayat (1) dan (2)UU kesehatan juga disebutkan mengenai fasilitas pelayanan kesehatan.

1) Fasilitas Pelayanan Kesehatan menurut jenis pelayanannya terdiri atas:

a) Pelayanan kesehatan perorangan; dan

b) Pelayanan kesehatan masyarakat.

2) Fasilitas pelayanan kesehatan sebagaimana dimaksud pada ayat (1) meliputi:

a) pelayanan kesehatan tingkat pertama;

b) pelayanan kesehatan tingkat kedua; dan

20 Jenny Sondakh, Marjati, Cahyani, Op.,Cit Hal 2-3. 
c) pelayanan kesehatan tingkat ketiga.

Kepala Puskesmas mengatakan dalam rangka meningkatkan mutu pelayanan sebagaimana tujuan dari pelaksanaan akreditasi yaitu puskesmas berupaya memberikan pelayanan yang terstandar sesuai dengan standard profesi, standard prosedur operasional (SOP), dengan mengutamakan keamanan dan keselamatan pasien. Berdasarkan hal tersebut Kepala Puskesmas mengatakan bahwa setiap pelayanan yang diberikan oleh dokter, perawat, dan bidan harus berdasarkan standar yang telah ditetapkan dalam hal ini standar prosedur operasional, dan standar profesi. ${ }^{21}$

Berdasarkan hasil wawancara dengan narasumber perawat penanggung jawab program imunisasi didapatkan hasil yaitu program imunisasi merupakan salah satu program unggulan di puskesmas, karena capaian yang diperoleh dari pelaksanaan program imunisasi ini melebihi target. Jadi masyarakat khususnya di daerah bahodopi sangat banyak karena adanya perusahaan nikel yang beroperasi di Kecamatan Bahodopi. Adapun jenis-jenis imunisasi yang diberikan mulai dari usia 0 bulan-5 tahun, mulai dari imunisasi HB o suntikan bayi baru lahir atau suntikan neonatus usia o bulan-7 hari, imunisasi lain yag diberikan yaitu BCG, DPT, Polio, campak dan untuk vaksin yang 1 tahun 6 bulan disebut DPT HB hip atau combo untuk suntikan tambahan, kemduian untuk campak tambahan di usia 2 tahun-3 tahun. $^{22}$

Dalam rangka meningkatkan kesehatan dan pemeliharaan kesehatan masyarakat salah satu kegiatan yang dilaksanakan yang berorientasi sasaran (UKMBS)yaitu kegiatan promosi kesehatan. Pada Undang-Undang No 39 tahun 2009 tentang Kesehatan pada Pasal 1 ayat (12) disebutkan bahwa "Pelayanan kesehatan promotif adalah suatu kegiatan dan/atau serangkaian kegiatan pelayanan kesehatan yang lebih mengutamakan kegiatan yang bersifat promosi kesehatan". Kegiatan promosi kesehatan pada UU kesehatan diatur dalam Pasal 12 ayat (5) disebutkan bahwa "Promosi kesehatan dilakukan melalui: penyuluhan, konsultasi, bimbingan dan konseling, intervensi perubahan perilaku, pemberdayaan, pelatihan, atau pemanfaatan media informasi". Pelayanan kesehatan promotif merupakan salah satu upaya pelayanan kesehatan yang diselenggarakan oleh puskesmas.

Salah satu upaya pencegahan yang dilakukan berdasarkan hasil wawancara yang dilakukan oleh pihak puskesmas yaitu pemberian obat pencegahan secara massal. Akan tetapi hal tersebut belum berjalan dengan optimal karena banyaknya jumlah penderita serta terbatasnya stok obat yang tersedia, jadi pihak puskesmas kewalahan dalam melayani penderita tuberkolosis. Untuk menindak lanjuti kejadian tersebut pihak puskesmas melakukan rujukan ke rumah sakit daerah agar memperoleh pengobatan lanjut.

Pada upaya kesehatan perorangan (UKP) beberapa peran perawat yaitu dalam Peningkatan Mutu Klinis dan Keselamatan Pasien (PMKP). Salah satu kegiatan yang dilakukan yaitu pelayanan gawat darurat. Peran perawat dalam pelayanan gawat darurat yaitu perawat menerima pasien, kemudian mencatat identitas lengkap dan jelas serta informed consent. Tindakan selanjutnya yaitu melakukan anamnesa,

${ }^{21}$ lbid.,

${ }^{22}$ Hasil Wawancara dengan penanggung jawab program imunisasi, pada tanggal 5 September 2018. 
pemeriksaan tanda-tanda fital, pemeriksaan fisik awal, pengelompokkan pasien dan diagnosa awal. Dalam rangka peningkatan mutu klinis dan keselamatan pasien perawat bertanggung jawab memberikan pelayanan yang berkualitas untuk pemenuhan kesehatan masyarakat. Tindakan kegawat daruratan merupakan keadaan yang mengancam jiwa untuk itu diperlukan perawat yang kompeten dalam memberi asuhan keperawatan, dan harus meningkatkan kemampuan dalam berbagai peran, serta mengerti karakteristik pelayanan keperawatan yang tepat, cermat, cepat, cara berkomunikasi dengan baik dalam kondisi darurat (emergency).

Berdasarkan hasil wawancara dengan narasumber dari ketiga puskesmas yaitu Puskesmas Laantula Jaya, Puskesmas Ulunambo, Puskesmas Bahodopi, didapatkan hasil sebagai berikut:

Hasil wawancara dengan narasumber di Puskesmas Laantula Jaya dapat ditarik simpulan bahwa pelaksanaan akreditasi memberikan manfaat atas status akreditasi puskesmas itu sendiri dengan adanya pengakuan yang diberikan oleh lembaga independen penyelenggara akreditasi yang ditetapkan oleh Menteri Kesehatan bahwa puskesmas telah memenuhi standar pelayanan dan juga sebagai pengguna jasa layanan yaitu masyarakat dengan adanya peningkatan mutu pelayanan yang diselenggarakan oleh puskesmas. Peningkatan mutu pelayanan yang diberikan oleh puskesmas didukung dengan hasil wawancara terhadap pengguna jasa layanan bahwa puskesmas Laantula Jaya telah berupaya memberikan pelayanan yang optimal terhadap masyarakat baik dalam upaya pelayanan kesehatan masyarakat maupun dalam upaya pelayanan kesehatan perorangan dipuskesmas. Pada pelayanan yang diselenggarakan diPuskesmas terdapat efisiensi waktu mulai saat pendaftaran sampai dengan pengambilan obat di apotik sudah baik. Berbeda halnya sebelum pelaksanaan akreditasi terjadi banyak antrian saat pelayanan. Berdasarkan hal tersebut puskesmas Laantula Jaya berupaya memberikan pelayanan yang optimal demi mewujudkan derajat kesehatan masyarakat yang setinggi-tingginya.

Adapun hasil wawancara dengan narasumber Puskesmas Ulunambo dapat ditarik simpulan bahwa Puskesmas Ulunambo dalam pelaksanaan akreditasi berupaya memberikan pelayanan yang bermutu sebagaimana tujuan dari penyelenggaraan akreditasi puskesmas yaitu untuk pembinaan peningkatan mutu kinerja melalui perbaikan yang berkesinambungan puskesmas memberikan pelayanan kesehatan kepada masyarakat berdasarkan standar profesi, standar prosedur operasional sesuai dengan ketentuan dalam standar akreditasi. Peran perawat dalam upaya kesehatan masyarakat berfokus pada kegiatan promosi kesehatan, dimana tujuan promosi kesehatan untuk meningkatkan dan memelihara serta mencegah penyakit. Adapun dalam upaya kesehatan peorangan lebih berfokus pada pelayanan dipuskesmas. Pada pelayanan perorangan pada puskesmas Ulunambo lebih berfokus pada pelayanan klinis dipuskesmas. Secara keseluruhan pada kegiatan yang dilaksanakan oleh puskesmas sudah berjalan dengan baik meskipun masih terdapat beberapa kekurangan pada pelaksanaan kesehatan masyarakat seperti belum tercapainya tingkat kesadaran yang baik pada masyarakat akan pentingnya perilaku hidup bersih dan sehat dalam kehidupan sehari-hari sehingga perlu adanya upaya dari puskesmas melalui penyuluhan-penyuluhan dan juga kordinasi lintas sektor yang belum berjalan optimal. Akan tetapi puskesmas Ulunambo selalu berupaya untuk memberikan pelayanan yang berkualitas bagi masyarakat. 
Adapun hasil wawancara dengan narasumber dipuskesmas Bahodopi dapat ditarik simpulan bahwa dalam penyelenggaraan pelayaan yang diberikan oleh Puskesmas Bahodopi belum berjalan secara optimal sesuai dengan standar akreditasi. Hal tersebut dapat terlihat dari ketersediaan sumber daya manusia kesehatan yang tersedia dipuskesmas tersebut. Ketersediaan sumber daya kesehatan sangat mempengaruhi terhadap pelayanan yang diberikan kepada masyarakat. Beberapa kegiatan yang dilaksanakan pada program upaya kesehatan masyarakat belum berjalan secara optimal seperti pemberian obat pencegahan secara massal, karena banyak jumlah penderita serta terbatasnya jumlah stok obat puskesmas cukup kewalahan menangani hal tersebut. Sehingga upaya terbaik yang dilakukan oleh puskesmas yaitu dengan memberikan rujukan untuk berobat ke rumah sakit agar memperoleh pelayanan kesehatan. Adapun pada upaya kesehatan perorangan, peran perawat pada peningkatan mutu pelayanan klinis yaitu dengan melakukan pelayanan gawat darurat. Dalam pelayanan gawat darurat tersebut perawat sangat berperan karena tidak tersedianya tenaga dokter pada puskesmas Bahodopi. Hal tersebut sesuai hasil wawancara dengan pengunjung bahwa akibat tidak teredianya tenaga dokter mengakibatkan tidak optimalnya pelayanan yang diberikan seperti waktu antrian saat pendaftaran, pemeriksaan, dan juga pengambilan obat. Jadi berdasarkan hal tersebut dapat ditarik simpulan bahwa Puskesmas Bahodopi dalam menyelenggarakan pelayanan kesehatan belum berjalan secara optimal berdasarkan sumber daya yang dimiliki, serta sistem manajemen puskesmas belum terorganisasi dengan baik.

\section{Faktor Pendukung dan Pengahambat Peran Perawat dalam Pelaksanaan Akreditasi Puskesmas untuk Peningkatan Mutu Pelayanan Kesehatan}

1. Faktor Pendukung

Faktor pendukung terhadap peran perawat dalam pelaksanaan akreditasi puskesmas:

a. Peraturan Perundang-Undangan

Negara mempunyai peranan lewat pemerintah untuk menyusun peraturan dalam memberikan perlindungan hukum terhadap setiap anggota masyarakat. Peraturan yang dikeluarkan oleh pemerintah salah satunya mengatur tentang kesehatan agar terciptanya pelayanan kesehatan yang optimal dan nondiskriminatif dan mewujudkan hak masyarakat dalam mendapatkan pelayanan kesehatan yang baik.

Pemerintah dan Pemerintah Daerah bertanggung jawab penuh terhadap pengembangan sumber daya manusia khususnya dalam bidang kesehatan. Pasal 4 butir a dan Pasal 5 butir e Undang Undang Nomor 36 Tahun 2014 tentang Tenaga Kesehatan bahwa "pemerintah dan pemerintah daerah bertanggung jawab terhadap pengaturan, pembinaan, pengawasan, dan peningkatan mutu tenaga kesehatan". Pasal 5 butir e bahwa "pemerintah dan pemerintah daerah bertanggung jawab dalam membina, mengawasi, dan meningkatkan mutu tenaga kesehatan melalui pelaksanaan kegiatan sertifikasi kompetensi dan pelaksanaan registrasi tenaga kesehatan".

Berdasarkan Peraturan Menteri Kesehatan No 75 tahun 2014 tentang Puskesmas, Puskesmas merupakan fasilitas pelayanan kesehatan yang menjadi garda depan dalam penyelenggaraan upaya kesehatan dasar khususnya dalam 
era JKN saat ini. Adapun kebijakan yang dilakukan oleh Kementerian Kesehatan dalam upaya peningkatan mutu pelayanan di fasilitas kesehatan tingkat pertama khususnya Puskesmas adalah dengan menerbitkan Peraturan Menteri Kesehatan No 46 tahun 2015 tentang Tentang Akreditasi Puskesmas, Klinik Pratama, Tempat Praktik Mandiri Dokter, Dan Tempat Praktik Mandiri Dokter Gigi.

Tenaga keperawatan dalam melaksanakan tugas dan tanggung jawabnya sebagai pemberi pelayanan kesehatan juga diatur dalam Pasal 1 ayat (3) Undang-Undang Nomor 38 Tahun 2014 tentang Keperawatan disebutkan bahwa "pelayanan keperawatan adalah suatu bentuk pelayanan profesional yang merupakan bagian integral dari pelayanan kesehatan yang didasarkan pada ilmu dan kiat keperawatan ditujukan kepada individu, keluarga, kelompok, atau masyarakat, baik sehat maupun sakit". Undang-Undang Nomor 38 Tahun 2014 tentang Keperawatan Pasal 37 dikatakan bahwa perawat memiliki kewajiban "memberikan pelayanan keperawatan sesuai dengan kode etik, standar pelayanan keperawatan, standar profesi, standar prosedur operasional, dan ketentuan peraturan perundang-undangan.

b. Sumber Daya Manusia

Ketersediaan sumber daya manusia sangat berpengaruh pada penyelenggaraan pelayanan kesehatan di puskesmas. Sebagian puskesmas mempunyai kendala dalam jumlah tenaga yang kompeten terhadap program kesehatan. Kendala tenaga ini sangat kecil bisa diatasi oleh puskesmas, dimana peraturan tidak memungkinkan puskesmas untuk menambah tenaga sendiri. Ketersediaan tenaga sangat tergantung dari tingkat yang lebih tinggi baik pemerintah kabupaten maupun pemerintah pusat.

2. Faktor Penghambat

Faktor penghambat terhadap peran perawat dalam pelaksanaan akreditasi puskesmas:

a. Ketersediaan Sumber Daya Kesehatan. Sebagaimana dimaksud pada Pasal 1 ayat (2) UU No 36 Tahun 2009 tentang Kesehatan, yaitu:

"Sumber daya di bidang kesehatan adalah segala bentuk dana, tenaga, perbekalan kesehatan, kesediaan farmasi dan alat-alat kesehatan serta fasilitas pelayanan kesehatan dan teknologi yang dimanfaatkan untuk meyelenggarakan upaya kesehatan yang dilakukan oleh Pemerintah, Pemerintah Daerah dan/atau Masyarakat".

Sebagian puskesmas mempunyai kendala dalam jumlah tenaga yang kompeten terhadap program kesehatan. Kendala tenaga ini sangat kecil bisa diatasi oleh puskesmas, dimana peraturan tidak memungkinkan puskesmas untuk menambah tenaga sendiri. Ketersediaan tenaga sangat tergantung dari tingkat yang lebih tinggi baik pemerintah kabupaten maupun pemerintah pusat.

b. Beban kerja petugas puskesmas

Keterbatasan tenaga di puskesmas menyebabkan satu tenaga bisa memegang beberapa program. Apabila mengacu pada standar akreditasi dimana satu program mempunyai SOP dan pertanggungjawaban tersendiri, maka bisa dibayangkan satu orang petugas harus membuat SOP dan 
pertanggungjawaban beberapa program, tentu saja hal tersebut akan mempengaruhi kinerja petugas kesehatan.

c. Sarana dan Prasarana Puskesmas

Kelengkapan sarana dan prasarana sebagai dasar untuk melakukan pelayanan yang terstandar belum sepenuhnya tersedia. Penilaian akreditasi akan mendasarkan pada sarana yang tersedia dalam melakukan pelayanan.

\section{KESIMPULAN}

1. Peran perawat dalam pelaksanaan akreditasi puskesmas untuk peningkatan mutu pelayanan kesehatan di Kabupaten Morowali

Peran perawat terkait pelaksanaan akreditasi sangat penting karena sebagai pemberi pelayanan kesehatan yang diselenggarakan oleh puskesmas. Dalam pelaksanaan akreditasi puskesmas terdapat 3 hal pokok yang menjadi instrumen penilaian yaitu Adminstrasi Manajemen, Upaya Kesehatan Masyarakat, dan Upaya Kesehatan Peorangan. Perawat dalam pelaksanaan akreditasi berperan pada ketiga hal pokok tersebut yaitu administrasi manajemen, upaya kesehatan masyarakat (UKM) dan upaya kesehatan perorangan (UKP) sesuai tugas dan kewenangannya. Sehingga dengan berperannya perawat pada ketiga instrumen tersebut diharapkan terciptanya pelayanan kesehatan yang berkualitas dan bermutu sehingga mampu mewujudkan derajat kesehatan masyarakat yang setinggi-tingginya serta hal tersebut akan memberi manfaat dalam suksesnya penyelenggaraan akreditasi puskesmas.

2. Faktor yang mendukung dan menghambat peran perawat dalam pelaksanaan akreditasi puskesmas di Kabupaten Morowali

Faktor pendukung peran perawat dalam pelaksanaan akreditasi puskesmas untuk peningkatan mutu pelayanan kesehatan yaitu Peraturan Perundang-Undangan dan Ketersediaan Sumber Daya Kesehatan. Negara mempunyai peranan lewat pemerintah untuk menyusun peraturan dalam memberikan kepastian hukum terhadap pelaksanaan akreditasi puskesmas. Peraturan tersebut merupakan kebijakan yang dilakukan dalam upaya peningkatan mutu pelayanan di fasilitas kesehatan tingkat pertama khususnya Puskesmas. Adapun Ketersediaan sumber daya manusia sangat berpengaruh pada penyelenggaraan pelayanan kesehatan di puskesmas. Sebagian puskesmas mempunyai kendala dalam jumlah tenaga yang kompeten terhadap program kesehatan. Kendala tenaga ini sangat kecil bisa diatasi oleh puskesmas, dimana peraturan tidak memungkinkan puskesmas untuk menambah tenaga sendiri. Ketersediaan tenaga sangat tergantung dari tingkat yang lebih tinggi baik pemerintah kabupaten maupun pemerintah pusat.

Faktor penghambat peran perawat dalam pelaksanaan akreditasi puskesmas untuk peningkatan mutu pelayanan kesehatan yaitutidak tersedianya sumber daya kesehatan setiap puskesmas sehingga perlunya penambahan tenaga kesehatan untuk menunjang pelayanan kesehatan yang efisien dan optimal, keterbatasan tenaga di puskesmas menyebabkan satu tenaga bisa memegang beberapa program, apabila mengacu pada standar akreditasi dimana satu program mempunyai SOP dan pertanggungjawaban tersendiri, maka seharusnya setiap perawat hanya memegang satu program kemudian ketidaklengkapan sarana dan prasarana akan mempengaruhi pelaksanaan pelayanan sehingga perlunya sarana dan prasarana yang memadai. 


\section{SARAN}

\section{Bagi Tenaga Kesehatan (Perawat)}

Tenaga kesehatan yang terlibat (perawat) sebagai tenaga kesehatan yang ada di masyarakat harus senantiasa mengembangkan dan meningkatkan ilmu pengetahuan dan kemampuan dalam melaksanakan tugas dan kewenangannya diharapkan dapat meningkatkan kualitasnya dimasyarakat.

Perawat harus mampu memberikan pelayanan kesehatan yang bermutu dan komprehensif (berkesinambungan, terpadu, dan paripurna), yang mencakup upaya promotif, preventif, kuratif dan rehabilitatif dalam upaya mencapai terwujudnya derajat masyarakat yang setinggi-tingginya.

\section{Bagi Puskesmas}

Puskesmas sebagai sarana dari penyelenggara upaya kesehatan bagi bangsa Indonesia demi meningkatkan kesadaran, kemauan serta kemampuan untuk hidup sehat bagi setiap wargademi terwujudnya derajat kesehatan masyarakat yang optimal. Ketersedian sumber daya kesehatan sangat mempengaruhi terhadap penyelenggaraan pelayanan kesehatan yang diberikan sehingga harus di optimalkan.

\section{Bagi Dinas Kesehatan Kabupaten Morowali}

a. Diharapkan melakukan peningkatan kapasitas sumber daya manusia (SDM) kesehatan sehingga tenaga kesehatan bisa bekerja sesuai dengan tugas dan kewenangannya.

b. Ketersediaan sumber daya kesehatan merupakan salah satu instrumen penting dalam pelaksanaan pelayanan kesehatan sehingga peran dinas kesehatan dalam memenuhi ketersediaan tersebut harus optimal.

\section{DAFTAR PUSTAKA}

Alamsyah Dedi, 2012, Manajemen Pelayanan Kesehatan. Yogyakarta: Nuha Medika.

Ali Zainuddin, 2016, Metode Penelitian Hukum, Jakarta: Sinar Grafika.

Dantes Nyoman, 2012, Metode Penelitian, Yogyakarta: CV Andi Offset

Gde Muninjaya, 2015, Manajemen Mutu Pelayanan Kesehatan, Jakarta: EGC.

Handayani Sri, 2011, Ilmu Politik dan Kebijakan Kesehatan, Yogyakarta: Gosyen Publishing.

Hendrik, 2018, Etika dan Hukum Kesehatan, Jakarta: EGC.

http://gajiroum.kemkes.go.id/data/UU_NO_36_2014.pdf

http://www.depkes.go.id/resources/download/general/UU\%20Nomor\%2036\%20Tahun2\%200 09\%20tentang\%20Kesehatan.pdf

http://www.depkes.go.id/resources/download/peraturan/PMK-No-75-Th-2014-ttg-

Puskesmas.pdf.

http://yankes.kemkes.go.id/assets/downloads/PMK\%20No.\%2046\%20\%20ttg\%20Akreditasi\%20 Puskesmas,\%20Klinik\%20\%20Pratama,\%20Tempat\%20Praktik\%20Mandiri\%2oDokter\% 20dan\%20Dokter\%20Gigi.pdf

https://www.persi.or.id/images/regulasi/uu/uu382014.pdf 
Jenny Sondakh, Marjati, Cahyani Pipit, 2014, Mutu Pelayanan Kesehatan dan Kebidanan, Jakarta: Salemba Medika.

Konli Steven, Pelayanan Kesehatan Masyarakat Di Puskesmas Desa Gunawan Kecamatan Sesayap Kabupaten Tana Tidung., eJournal Ilmu Pemerintahan, 2014, 2 (1): ISSN 2338-3615 hal1925-1936. http://ejournal.ip.fisipunmul.ac.id/site/wpcontent/uploads/2014/03/Jurnal\%20Steve n\%20IP\%202010\%20(03-01-14-12-07-23).pdf diakses tanggal 27 maret 2018 jam 22.27 WIB.

Peraturan Menteri Kesehatan No 46 tahun 2015 tentang Akreditasi Puskesmas, Klinik Pratama, tempat Praktik mandiri Dokter, dan tempat Praktik mandiri Dokter Gigi

Peraturan Menteri Kesehatan No 75 tahun 2014 tentang Puskesmas

Ratnawati Emmelia, 2014, Keperawatan Komunitas, Yogyakarta: Pustaka Baru Press.

Rianto Adi, 2005, Metode Penelitian Sosial dan Hukum, Jakarta: Granit.

Tribowo Cecep, 2010, Hukum Keperawatan, Yogyakarta, Pustaka Book Publisher.

Undang-Undang Dasar Negara Republik Indonesia tahun 1945 http://jdih.pom.go.id/uud1945.pdf

Undang-Undang No. 38 tahun 2014 tentang Keperawatan

Undang-Undang Nomor 36 tahun 2009 tentang Kesehatan

Undang-Undang Nomor 36 tahun 2014 tentang Tenaga Kesehatan 